\title{
ASh Yellows in ZiON National PARK: IMPACT, IDENTITY OF PATHOGEN, MODE OF SPREAD, AND Prospects fOR MANAgemENT
}

\author{
WAYNE A. SINCLAIR \\ DEPARTMENT OF PLANT PATHOLOGY \\ CORNELL UNIVERSITY \\ ITHACA
}

\author{
MICHAEL TRESHOW \\ DEPARTMENT OF BIOLOGY \\ UNIVERSITY OF UTAH \\ SALT LAKE CITY
}

\author{
ROBERT E. DAVIS \\ MICROBIOLOGY AND PLANT PATHOLOGY LABORATORY \\ ARS, USDA, PLANT SCIENCE INSTITUTE \\ BELTSVILLE
}

Velvet ash (Fraxinus velutina) in Zion Canyon have declined in vigor, and some are dying. This species is aesthetically and ecologically important in the canyon, because it is one of only three tree species that commonly grow to large size on the canyon floor. Ash yellows (AshY), a disease caused by unnamed mycoplasmalike organisms (MLOs), is common in velvet ash in Zion Canyon and is suspected to contribute to the decline of this species. This project deals with the ecology and epidemiology of ash yellows and possibilities for managing it in Zion National Park (ZNP).

\section{$\checkmark$ RESEARCH OBJECTIVES}

1. Determine the extent of-damage to the ash species in ZNP, and map the distribution of ash yellows in the park. A survey along highways in and near ZNP revealed that velvet ash is concentrated in Zion and North Creek Canyons in the upper Virgin River watershed. Many trees of this species in the Zion Canyon displayed dieback. Severe, repeated defoliation by insects (mainly loopers), which affected not only ash but boxelder and Fremont cottonwood as well, was judged to be the principal cause of dieback. Foliar damage to velvet ash by plant bugs (Tropidosteptes pacificus) and a lacebug (Leptyphyri sp.) was also prominent. Mature trees of all three species on deep sandy soils were apparently also stressed by water shortage. Of 174 velvet ash in all vigor classes, sampled on 15 sites in the canyon and diagnosed by means of the DAPI fluorescence test, $38 \%$ were found to be infected with MLOs. The frequency of MLO detection was greater in symptomatic ash than in apparently healthy ash. On average, MLO-infected ash also grew less rapidly during the decade 19801989 than did ash without MLOs. These findings were consistent with the hypothesis that MLOs play a role in the decline of velvet ash in Zion Canyon. MLOs were not detected in singleleaf ash ( $F$. anomala).

2. Learn whether or not the MLOs in ash in ZNP are closely related to those associated with ash 
yellows in Nevada and New York. Preliminary evidence was obtained that the MLOs in velvet ash in Zion Canyon are related to MLOs associated with ash yellows in the East. DNA from one diseased velvet ash, but not from healthy white ash ( $F$. americana) used as a control, hybridized with AshY-specific cDNA probes derived from genomic DNA of an eastern strain of ash yellows MLO. Dot hybridizations, whether with AshY-specific probes or a nonspecific probe that detects diverse MLOs, failed to detect MLOs in 14 of 15 other diseased ash in which MLOs had been detected by means of the DAPI fluorescence technique. Low MLO titer in velvet ash and a consequent insufficiency of MLO DNA in the extracts tested were believed responsible for the negative results. This aspect of the project is being continued using the polymerase chain reaction for DNA amplification.

3. Determine the means and rate of spread of ash yellows and the rate at which the epidemic is progressing within the currently affected area. Insects, probably leafhoppers, are presumed to transmit AshY MLOs. Collection of homoteran insects associated with velvet ash began in 1990 with the aim of eventually detecting MLOs on one or more species by means of DNA hybridization tests. Possible alternative plant hosts of AshY MLOs were also sought. Ten sites in Zion Canyon were searched for plants, other than ash, with symptoms possibly caused by MLOs. Plants that were dwarfed or chlorotic or with bunched shoots or witches'brooms were given particular attention. Only approximately 30 suspect plants were found, and MLOs were detected, by means of the DAPI test, in only two plants, both of which awaited identification. The lack of common detection of MLOs in plants other than velvet ash let to the tentative interpretation that the MLOs causing AshY in Zion Canyon do not have alternative host plants. A study of disease spread in the ash population began by sampling ash trees for diagnosis and marking them so that those found to be not infected with MLOs could be retested in 1991 and 1992.

4. Assess the possibilities for managing the disease. Experiments began for evaluation of kinetin solutions for chemotherapy of MLOinfected ash and other plants. Five-year-old white ash seedlings were inoculated with MLOs by grafting with diseased bark patches, and control seedlings were left ungrafted. Additionally, MLO-infected and healthy periwinkle (Catharanthus roseus) plants were propagated by cuttings. Treatments of both plant species were scheduled for summer, 1991.

\section{SURVEY FOR ASH DECLINE IN ZNP}

The survey was extended to North Creek Canyon, a location that had been missed in 1990. The velvet ash population there, brought to our attention by NPS personnel, is the only significant one other than that in the main canyon within ZNP. North Creek Canyon is $12-15 \mathrm{~km}$ west of Zion Canyon and separated from it by high country devoid of ash. It was of interest to learn whether or not MLOs occur in velvet ash in North Creek Canyon, and if so, whether the frequency of infection is similar to that detected in Zion Canyon. Occurrence of AshY in both canyons could indicate overland spread of the MLOs by wind-borne vectors, since the part of North Creek within the park is undeveloped and plant materials have not been brought into it by people. Presence of AshY in both North Creek and Zion Canyons could also indicate that the AshY MLOs are indigenous to the Zion area. Lack of occurrence of AshY in North Creek Canyon would indicate that MLOs may have been introduced to Zion Canyon, where they have been spread by indigenous vectors.

Two sites along the creek bed, separated by approximately $7.5 \mathrm{~km}$, were visited. Thirty-nine velvet ash at one site and 31 at the other were rated for vigor and sampled for diagnosis using procedures described in previous reports. Most of the ash observed were saplings, of which about equal numbers were scored as vigorous or growing slowly. Symptoms of decline (dieback of branches) were infrequent in the saplings but were observed in nearly all ash larger than saplings. MLOs were detected in ash at both sites but in only a total of three plants, one growing slowly and two with dieback. Thus, the proportion of ash infected (4\%) was markedly lower than that previously detected in Zion Canyon (38\%).

The finding of MLO-infected ash at two locations in North Creek Canyon is consistent with the hypothesis that overland spread of AshY MLOs by windborne vectors has occurred in ZNP. This 
finding neither supports nor refutes the hypothesis that AshY MLOs were introduced to ZNP from elsewhere, but it does raise the possibility that MLOinfected velvet ash may be found in additional locations in southwestern Utah and adjacent areas.

\section{ASSOCIATION OF MYCOPLASMALINFECTION WITH DECLINE OF VELVET ASH IN ZION CANYON}

Previous observations and samples were augmented by adding three plots and 119 trees to those under study and by reexamining most trees that were first observed in 1990. In all, 240 trees and 142 samplings on 19 sites have been examined and sampled for possible MLO detection. The new plots and the augmented samples on previously established plots were all in the northern half of the canyon, where human disturbance to the landscape has been less dramatic than in the southern half. As before, trees representing the range of health and debilitation on each plot were examined, assigned to vigor categories, and sampled (small roots) for possible microscopic detection of MLOs by means of the DAPI fluorescence test (Sinclair et al. 1989).

MLOs were detected in $27 \%$ of the newly sampled trees and saplings, versus $38 \%$ of those sampled in 1990 , for an overall $32 \%$ infection rate. The proportion of trees larger than saplings infected with MLOs did not differ significantly among vigor categories (Table 1). Thus, the previous preliminary finding of a higher proportion of MLO-infected individuals among trees with dieback than among trees without this symptom was not sustained.

In the sapling group (1-6 cm dbh) (Table 2), MLOs were detected in $44 \%$ of the 32 individuals with dieback (health categories $3+4$ ) versus $26 \%$ of the 92 individuals without dieback (health categories 1 and 2). With 0.26 as the expected proportion infected, the calculated Chi-square value for observed incidence of MLO infection in saplings with dieback was 3.91; the associated probability level with one degree of freedom was $<0.05$. Because only 17 vigorous saplings and only 32 with dieback were

Table 1. DAPI test scores in relation to health categories of velvet ash trees larger than $6 \mathrm{~cm} \mathrm{dbh}$.

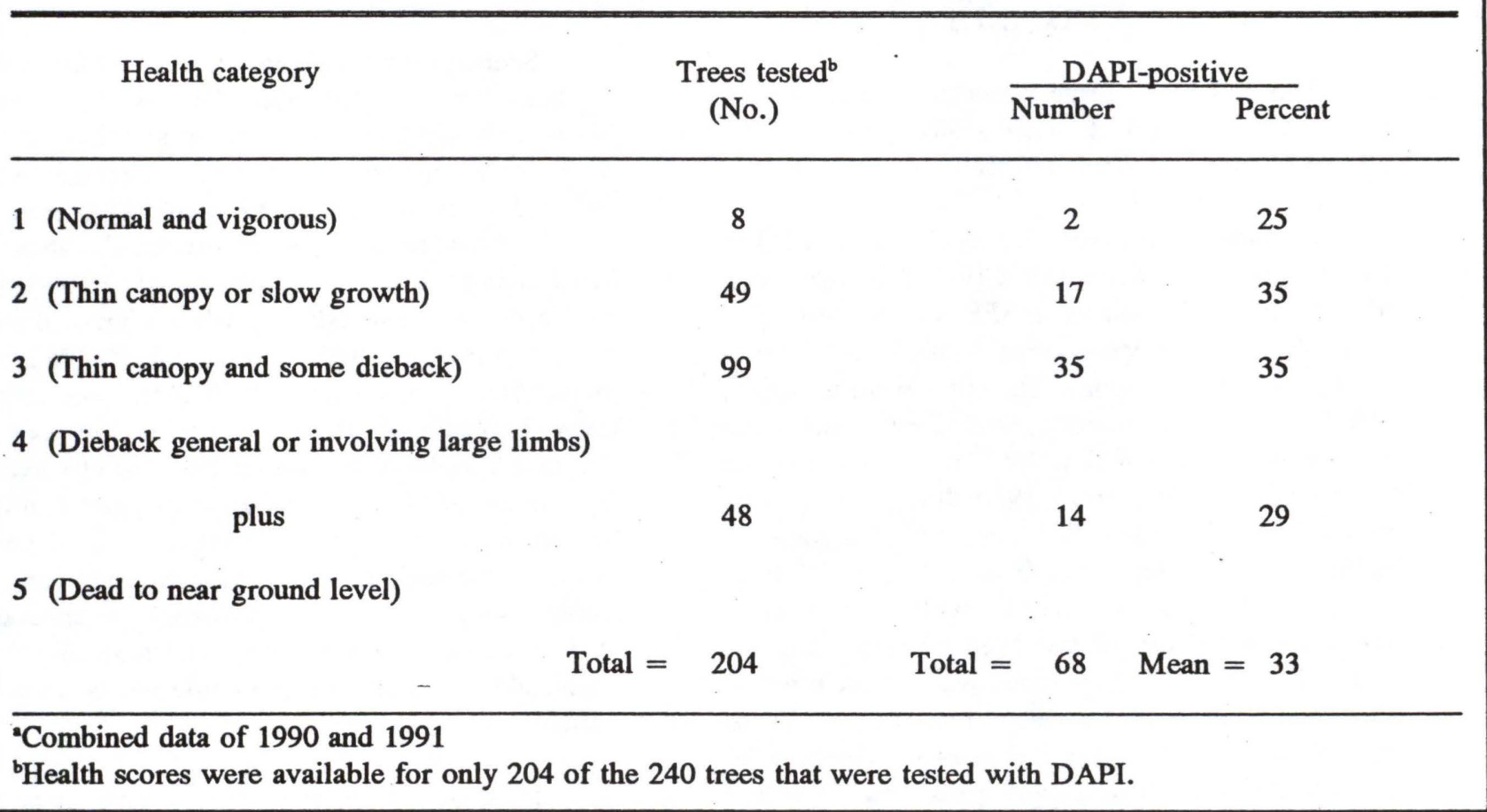


Table 2. DAPI test scores in relation to health categories of velvet ash saplings $\leq 6 \mathrm{~cm} \mathrm{dbh}$.

\begin{tabular}{lcc}
\hline \multicolumn{1}{c}{ Health category } & $\begin{array}{c}\text { Trees tested } \\
\text { (no.) }\end{array}$ & $\begin{array}{c}\text { DAPI-positive } \\
\text { (\%) }\end{array}$ \\
\hline Normal (vigorous) & 17 & 41 \\
Thin crown or slow growth & 75 & 23 \\
Thin crown and some dieback & 32 & 44 \\
$\quad$ or & Total $=$ & 124 \\
Dieback general & Mean $=$ & 31 \\
\hline
\end{tabular}

available for testing, interpretation of these data must remain uncertain. One available interpretation, however, is that MLO infection may have contributed to the debilitation of some saplings.

\section{RADIAL GROWTH OF VELVET ASH IN RELATION TO MLO INFECTION}

This part of the project was completed with the finding that MLO infection has probably retarded the growth of many velvet ash in ZNP.

Increment cores representing two radii at $1.3 \mathrm{~m}$ above ground were extracted in 1990-1991 from each of 106 trees for which DAPI scores were also available. These trees were located on 10 sites throughout Zion Canyon. The cores were air dried, glued to wooden supports, and sanded for clear display of annual growth rings. The aggregate width of the growth rings from 1980 through 1989 was measured to the nearest $0.1 \mathrm{~mm}$, recorded for each radius, and averaged for each tree. For the $\mathbf{4 5}$ trees sampled in 1990, the width of the widest growth ring, the aggregate width of the 1988-90 rings, and the years in which sudden, sustained reductions of growth occurred were also recorded. These reductions were recorded for years in which radial growth diminished to less than approximately one-half the average of the two previous years and remained slow thereafter. Increment cores were also extracted from two box elders and two cottonwoods on each of three sites where cores were taken from velvet ash. The objective of these collections was to compare growth trends of the three species over time, so that growth reductions occurring only in ash could be identified.

Sudden growth reductions occurred in $\mathbf{3 0}$ of the 45 trees that were examined for this characteristic. These reductions were not related to MLO infection as revealed by the DAPI test. Eighteen of 26 infected trees and 12 of 19 noninfected trees had sustained sudden reductions in growth. Because these reductions could not be related to MLO infection, it was not possible to estimate when a given diseased tree became infected. The cause(s) of these reductions are unknown. Defoliation by insects can cause dramatic growth reductions in various trees. Because we observed severe defoliation of velvet ash by loopers in 1990 and 1991, we suggest that these insects may have been a common cause of growth reductions in earlier years. The intended interspecific comparisons to detect growth fluctuations common to different species were not made, because ring widths in boxelder and cottonwood could not be measured reliably.

Most of the ash trees from which cores were extracted were growing slowly $(<1 \mathrm{~mm} / \mathrm{yr}$ ) in 19881990. For the 45 trees sampled in 1990, the average 
growth rate during 1988-1990 was not clearly related to MLO infection. Therefore, we examined the possible relationship of MLO-infection detected in 1990-1991 to radial growth during the previous 10-yr period. Radial growth in the decade 1980-1989 averaged $1.18 \mathrm{~mm} / \mathrm{yr}$ in the 41 infected trees and $1.32 \mathrm{~mm} / \mathrm{yr}$ in the 65 noninfected trees. This difference was not statistically significant $(\mathrm{P}<.05)$.

MLOs are known to cause slow growth and decline of various trees species, including white ash (Ferris et al. 1989, Hiruki 1988, Matteoni and Sinclair 1985, Sinclair et al. 1990). If MLOs suppress the radial growth of velvet ash only moderately, this suppression may be undetectable in trees already growing slowly because of other stresses. The average annual radial growth of $\mathbf{5 5}$ trees on three sites in the north end of the canyon was only $0.85 \mathrm{~mm}$. Because these trees had grown more rapidly earlier in their lives, and because severe defoliation by insects was observed in the northern half of the canyon in both 1990 and 1991, we suspect that velvet ash there may have been severely stressed by defoliation throughout the decade. (Note: defoliation in every year would not be needed to create this chronic stress.)

To test further for possible growth suppression of velvet ash by MLOs, we segregated all sampled trees into two arbitrary groups according to their average annual growth rate in 1989-1989: those that grew less than $1.0 \mathrm{~mm}$ per year and those that grew $1.0 \mathrm{~mm}$ or more per year. The growth rates of infected versus noninfected trees within groups were then compared. Among the 49 trees that grew less than $1.0 \mathrm{~mm}$ in $1980-1989$, the growth difference between MLO-infected and noninfected trees was negligible $(0.67$ versus $0.63 \mathrm{~mm}$ per year, respectively). Among trees that grew at least 1.0 mm per year on average, however, the growth rates of the 24 infected trees tended to be slower (av. 1.54 $\mathrm{mm} / \mathrm{yr}$ ) than those of the 33 noninfected trees (av. $2.00 \mathrm{~mm} / \mathrm{yr}$ ). A $t$-test for unpaired samples yielded a $t$-statistic of 1.93 with an associated probability of 0.059 .

We draw two interpretations from the above data. 1) MLO infection probably suppresses growth of velvet ash (growth of infected trees was $23 \%$ less than that of noninfected trees in the group mentioned above). 2) An influence of MLO infection on radial growth of velvet ash can not be detected in trees that are already growing very slowly (i.e., less than 1.0 $\mathrm{mm} / \mathrm{yr})$.

The research to date on dieback and slow growth of velvet ash in relation to MLO infection indicates that MLOs probably do not alone cause major debilitation of this species. In $\mathrm{ZNP}$, chronic foliar damage by loopers, ash plant bugs, and lacebugs, and water stress in many mature trees on sandbars may be primarily responsible for the symptoms of distress in this species.

Although the examination of growth rings did not reveal how long velvet ash in Zion Canyon have been infected with MLOs, these organisms may have been present for many years, because the growth trends of currently infected trees have been diverging from the trends in noninfected trees for at least a decade. These findings are in line with those for MLO-infected white ash in the East (Han et al. 1991, Sinclair et al. unpublished). Our preliminary conclusion regarding disease management is that even if a means to control ash yellows were available, measures directed specifically at this disease in ZNP would probably not be justified as long as severe insect problems and annual water stress in trees on sandbars persist.

Ten singleleaf ash were added to the 36 previously sampled for diagnostic examination by means of the DAPI test. As before, MLOs were not detected. To assess the susceptibility of this species to AshY MLOs, bark patches from roots of two diseased velvet ash saplings were grafted into the stems of the 10 newly sampled singleleaf ash. Results will be assessed in 1992.

Seeds of singleleaf ash, collected in ZNP in 1990 , were to be used to produce seedlings for inoculation by grafting with diseased bark patches from velvet ash and white ash. The seeds failed to germinate, however, so this test is deferred.

\section{IDENTIFICATION OF ASHY MLOS IN ZNP BY HYBRIDIZATIONS WITH CLONED BIOTINYLATED DNA PROBES}

Preliminary evidence was obtained (Table 3) that the AshY MLOs in ZNP are closely related to a New York strain of AshY MLO. 
Table 3. Representative dot hybridization results with biotinylated probes specific for ash yellows MLOs (AA probes) or nonspecific (pBB115).

Intensity of hybridization signal ${ }^{\mathrm{a}}$ with probe

Sample source

AA13I AA82I

$\underline{\text { AA157I }}$ AA176I

pBB115

Diseased ash

Ithaca, NY; white ash

2

3

2

3

3

Ithaca, NY; white ash

1

2

1

1

2

Tully, NY; white ash

0

2

1

2

2

Zion N.P.; velvet ash TN1

1

1

1

1

1

Zion N.P.; velvet ash M6

0

1

0

0

0

\section{$\underline{\text { Controls }}$}

Periwinkle with MLO strain AshY1

2

4

2

3

3

Periwinkle with MLO strain CX

$$
0
$$

0

0

0

4

Healthy white ash

0

0

0

0

0

Healthy periwinkle

0

0

0

0

0

${ }^{2}$ Hybridization signals were scored 0 (no signal) to 5 (intense).

This line of work was suspended during 1991 because dot hybridizations were not sufficiently sensitive to detect MLOs reliably. MLO DNA could not be detected, using either AshY-specific (Davis et al., in press) or nonspecific cDNA probes, in most of the infected velvet ash (DAPI test positive) that were sampled. The DAPI test was more sensitive than dot hybridizations utilizing either biotin-labeled or ${ }^{32} \mathrm{P}$ labeled probes (Griffiths et al. 1991, Sinclair et al. 1992). The relative insensitivity of dot hybridizations was apparently due to low titer of MLOs in velvet ash; thus, the amount of MLO DNA extracted fromsamples of velvet ash was low. To overcome the problem, arrangements have been made for detection of MLO DNA by polymerase chain reaction (PCR). Portions of four AshY-specific cDNA probes have been sequenced and certain sequences selected for synthesis as oligonucleotide primer sets. These primer sets will be available in early winter, 1991. We will then resume work on the question of relatedness of AshY MLOs in ZNP to those associated with AshY in the East.

Segments of roots of diseased velvet ash saplings were used as sources of bark patches that were grafted into stems of 5-yr-old white ash seedlings in a greenhouse at Ithaca. Roots rather than stems were chosen because the titer of MLOs in roots is likely to be higher than that in stems of velvet ash (Sinclair et al. in press). Unions formed between the bark patches and recipient stems, symptoms appeared during the remainder of the growth period in which grafting was done. Because the incubation period of AshY is often equivalent to 
nearly one growth cycle, symptoms may appear after the dormant period. The inoculated plants will be evaluated for symptoms and for MLO infection (DAPI test) in 1992.

\section{MYCOPLASMAL INFECTION IN PLANTS OTHER THAN ASH IN ZNP}

The two MLO-infected plants found in 1990 were identified as hairy golden aster (Chrysopsis villosa) and rabbitbrush (Chrysothamnus villosa). No additional plants, other than ash, infected with MLOs were found in 1991. Dot hybridization tests with DNA extracted from the dried diseased hairy golden aster were inconclusive (insufficient DNA obtained). These tests will be redone in 1992 using polymerase chain reaction to amplify target DNA. Based on the low incidence of detection of MLOs in plants other than ash, we do not expect to find a relationship between the MLOs in ash and those in hairy golden aster or rabbitbrush. Studies in parallel with this aspect of the work in ZNP have been proceeding in the east. To date, the only plants other than Fraxinum spp. found naturally infected with AshY MLOs have been members of the closely related genus Syringa (Hibben et al. 1991). We therefore anticipate that further work will sustain the working hypothesis that AshY MLOs in ZNP do not have alternative plant hosts.

\section{VECTOR DETECTION AND IDENTIFICATION}

Homopteran insects associated with velvet ash were collected on yellow sticky traps for 1-week periods every third week from early May through late September in 1991. The traps were sent to Ithaca and the insects removed and stored dry for later sorting by species and for attempts at MLO detection. These attempts will utilize a polyclonal antibody (currently being developed) for nonspecific detection of MLOs and AshY-specific PCR for detection of DNA of AshY MLOs. Insect groups in which some individuals are found to contain AshY MLOs will then be identified to genus and species.

\section{INCREASE OF ASHY IN ZION CANYON}

Information about the rate at which new MLO infections are occurring in Zion Canyon will be obtained in 1992 and 1993 by annually testing saplings and larger trees that were first sampled and scored negative in DAPI tests of 1990-1991. Retesting on a small scale began in 1991, with the finding of seven infected individuals among 22 that had been scored negative in 1990 .

\section{SEASONAL AND ANNUAL CONSISTENCY OF MLO DETECTION BY THE DAPI TEST}

Because detection of MLOs in velvet ash is often difficult, and because the proportion of sampled trees in which MLOs were detected in May 1991 (28\%) was lower than that in 1990 (38\%), we wonder if seasonal or annual fluctuations in MLO populations within trees may affect the results of DAPI tests. We therefor intend to repeatedly retest a sample of trees that were scored as infected in 1990. The plan is to select 50 infected trees for sampling in May and August of 1992 and possibly again in 1993. The need for this study is underscored by the results of tests in May 1991 of five trees that were found to be infected in 1990: three were rated noninfected in 1991.

\section{CHEMOTHERAPY EXPERIMENT}

The purpose was to learn whether kinetin causes remission or cure of AshY, as was reported by Plavsic et al. (1988) for the mycoplasmal disease called stolbur in tomato and potato.

In June 1990, approximately 55 healthy, potted 5-yr-old white ash seedlings that had completed their annual height growth were inoculated with AshY MLOs by grafting with bark patches from a diseased white ash growing at Ithaca. The grafts were wrapped in parafilm. Fifteen nongrafted seedlings served as controls. The height of every plant was measured. In 1991 the plants were tested for MLO infection (DAPI test), the vigor of each plant was scored (normal, slow growth, or new growth stunted), and the longest new shoot on each plant was measured. Plants taller than $70-75 \mathrm{~cm}$ were then pruned back to this height in order to maintain manageable size. Twenty-seven diseased and 14 healthy trees were suitable for the experiment. In July, diseased trees in the various vigor classes were distributed more or less equally into treatments, as follows: $\mathbf{3}$ modes of application (spray, soil drench, injection) $\times 3$ concentrations of kinetin $(0,1.0$, and $5.0 \mu \mathrm{M}) \times 3$ replicate plants per treatment. Healthy trees were assigned to treatments as follows: two to each of the six kinetin treatments above zero 
concentration, and two plants that each received all the zero kinetin treatments (spray, drench, and injection). Sprays (each solution containing 5 drops of Tween 20 per liter to wet foliage) were applied to runoff daily for 7 days. Drenches were administered at the rate of $100 \mathrm{ml}$ per plant twice 7 days apart. Injections to deliver $5 \mathrm{ml}$ of solution into each stem were performed once. The method of injection was to fasten a reservoir to each stem such that the liquid in the reservoir was in contact with the bark. An incision through the bark into xylem was then made, and the plant was allowed to take up the liquid by transpirational pull. Treated ash were observed for 2 months for any change in appearance and were then placed in a cold room to undergo a period of dormancy before further observations.

A similar experiment was performed with periwinkle plants infected with a strain of AshY mlo. Diseased and healthy periwinkles were propagated by cuttings in April 1991. In July 60 diseased plants and 27 healthy controls were assigned to treatments. For the diseased plants there were 4 concentrations of kinetin $(0,0.2,1.0$, and 5.0 micromolar $) \times 3$ modes of application (drench, spray, injection) $\times 5$ replicate plants per treatment. For the healthy plants there were 3 concentrations of kinetin $(0.2,1.0$, and 5.0 micromolar) $\times 3$ modes of application as above $\times 3$ replicate plants per treatment. Spray and drench treatments were performed as for ash trees, except that drench volumes were $50 \mathrm{ml}$. The injection treatments were intended to deliver $1.0 \mathrm{ml}$ into each stem, but a satisfactory leakproof method was not found, and most of the injected plants received only fractions of the intended doses of kinetin, Plants were then observed for 2 months.

No change in symptoms occurred in any treated or untreated ash or periwinkle during a 2-month observation period. All diseased plants remained stunted and bushy; all healthy plants remained vigorous. Healthy periwinkles had to be pruned once during the experiment to control their size. Random microscopic diagnoses of periwinkles by means of the DAPI test revealed no effect of treatments on the appearance or abundance of fluorescent particles in diseased phloem. We concluded that kinetin treatments had no effect on the MLOs or the disease in periwinkle. Final observations and DAPI tests on treated ash will occur in 1992. At present, however, we have no indication that an effect of treatment, either beneficial or adverse, will be detected.

\section{$-\quad$ CONTINUING STUdIES}

\section{MICOPLASMALINFECTIONIN PLANTS OTHER THAN ASH IN ZNP}

Field searches to detect additional MLOinfected plants will continue. To learn whether or not the MLOs that we may detect, or those previously detected in hairy golden aster and rabbitbrush, are related to AshY MLOs, DNA hybridization tests using polymerase chain reaction for amplification of target DNA will be performed with nonspecific and AshY-specific cDNA probes.

\section{IDENTIFICATION OF ASH YELLOWS MLOS IN ZNP BY HYBRIDIZATIONS WITH CLONED BIOTINYLATED DNA PROBES}

This line of work will resume in winter, 199192, when we expect to obtain capability for DNA amplification by PCR.

\section{VECTOR DETECTION AND IDENTIFICATION}

Insect collection will continue in 1992. Those collected will be sorted into homogeneous groups for possible MLO detection and identification using serological and recombinant DNA techniques as noted above.

\section{SPREAD OF ASHY}

All trees and samplings in Zion Canyon that were previously scored negative in DAPI tests will be retested to learn whether the proportion of trees diseased is increasing.

\section{YEAR-TO-YEAR CONSISTENCY OF POSITIVE RESULTS OF DAPI TESTS}

Fifty trees previously scored positive in DAPI tests will be retested in May and August of 1992 and possibly also in 1993 to ascertain the level of springto-summer and year-to-year consistency of positive results in velvet ash. 


\section{SUSCEPTIBILITY OF WHITE ASH TO MLOS FROM VELVET ASH}

Plants inoculated in 1991 will be evaluated for MLO infection (DAPI test) and for symptoms in 1992. If no infections are detected, the experiment will be repeated.

\section{SUSCEPTIBILITY OF SINGLELEAF ASH TO ASHY MLOS}

Plants grafted in the field in 1991 will be examined and tested (DAPI test) for evidence of MLO infection. If no infections are detected, the experiment will be repeated. Also, another attempt will be made to produce singleleaf ash seedlings for greenhouse tests of their susceptibility to AshY MLOs.

\section{CHEMOTHERAPY FOR CONTROL OF ASHY}

Final evaluation of kinetin-treated white ash seedlings will be made in 1992 . We expect that no effect of treatment will be detected.

\section{- ACKNOWLEDGEMENTS}

The insect collections in 1991 were made possible through the cooperation of Victor Vieira and Frank Hayes of the National Park Service, whose help we gratefully acknowledge.

\section{$\checkmark \quad$ LITERATURE CITED}

Davis. R. E., W. A. Sinclair, I.M. Lee, and E. L. Dally. 1991. Cloned DNA probes specific for detection of a mycoplasmalike organism associated with ash yellows. Molec. PlantMicrobe Interact. In press.

Ferris, M. A., J. D. Castello, and W. A. Sinclair. 1989. Effects of virus and mycoplasmalike organism infection on white and green ash. Phytopath. 79:579-583.

Griffiths; H. M. W. A. Sinclair, I. M. Lee, and R. E. Davis. 1991. DAPI fluorescence versus DNA probes for detecting mycoplasmalike organisms in woody plants and insects.
(Abstr.) Phytopath. 81:1210.

Han, Y., J. D. Castello, and D. J. Leopold. 1991. Ash yellows, drought, and decline in radial growth of white ash. Plant Dis. 75:18-23.

Hibben, C. R., W. A. Sinclair, R. E. Davis, and J. Alexander. 1991. Relatedness of mycoplasmalike organisms associated with ash yellows and lilac witches'-broom. Plant Dis. 75:(In press).

Hiruki, C., ed. 1988. Tree Mycoplasma diseases and epidemiology. University of Alberta Press, Edmonton. 245 pp.

Matteoni, J. a., and W. A. Sinclair. 1985. Role of the mycoplasmal disease, ash yellows, in decline of white ash in New York State. Phytopath. 75:355-360.

Plavsic, B., K. Krivokapic, and Z. Eric. 1988. Kinetin treatment of stolbur diseased plants and possibility of its application in chemotherapy. Pages 417-430 In: Mycoplasma Diseases of Crops. K. Maramorosch and S. Pl Raychaudhuri, eds. Springer-Verlag, New York. $456 \mathrm{pp}$.

Sinclair, W. A., H. M. Griffiths, R. E. Davis, and I. M. Lee. 1992. Detection of ash yellows mycoplasmalike organisms in different tree organs and in chemically preserved specimens by a DNA probe versus DAPI. Plant Dis. (In press).

Sinclair, W. A., H. M. Griffiths, M. Treshow, and R. E. Davis. 1991. Ash yellows endemic in Zion National Park, Utah. (Abstr.) Phytopath. 81:1235.

Sinclair, W. A., R. J. Iuli, A. T. Dyer, P. T. Marshall, J. A. Mateoni, C. R. Hibben, G. R. Stanosz, and B. S. Burns. 1990. Ash yellows: geographic range and association with decline of white ash. Plant Dis. 74:604-607.

Sinclair, W. A., R. J. Iuli, A. T. Dyer, and A. O. Larsen. 1989. Sampling and histological procedures for diagnosis of ash yellows. Plant Dis. 73:432-435. 